Article

\title{
Genetic Diversity and Stability of Performance of Wheat Population Varieties Developed by Participatory Breeding
}

\author{
Gaëlle van Frank ${ }^{1, *(1)}$, Pierre Rivière ${ }^{2}$, Sophie Pin ${ }^{1}$, Raphaël Baltassat ${ }^{2}$, \\ Jean-François Berthellot ${ }^{2}$, François Caizergues ${ }^{2}$, Christian Dalmasso ${ }^{2}$, \\ Jean-Sébastien Gascuel ${ }^{2}$, Alexandre Hyacinthe ${ }^{2}$, Florent Mercier ${ }^{2}$, Hélène Montaz ${ }^{2}$, \\ Bernard Ronot ${ }^{2}$ and Isabelle Goldringer $1, *$ (D) \\ 1 GQE- Le Moulon, INRAE, Univ. Paris-Sud, CNRS, AgroParisTech, Université Paris-Saclay, \\ 91190 Gif-sur-Yvette, France; sophie.pin@inra.fr \\ 2 Réseau Semences Paysannes, 47190 Aiguillon, France; pamriviere@protonmail.com (P.R.); \\ raph.baltassat@net-c.com (R.B.); Jean-francois.berthellot@wanadoo.fr (J.-F.B.); fcaizergues@yahoo.fr (F.C.); \\ chdalmasso@wanadoo.fr (C.D.); js.gascuel@63.sideral.fr (J.-S.G.); alexandreh@riseup.net (A.H.); \\ fl.m@laposte.net (F.M.); technique.grainesdenoe@gmail.com (H.M.); ronotbernard@gmail.com (B.R.) \\ * Correspondence: gaelle.van.frank@gmail.com (G.v.F.); isabelle.goldringer@inra.fr (I.G.)
}

Received: 30 October 2019; Accepted: 24 December 2019; Published: 3 January 2020

check for updates

\begin{abstract}
Modern agricultural systems rely on reduced crop genetic diversity, due in particular to the use of homogeneous elite varieties grown in large areas. However, genetic diversity within fields is a lever for a more sustainable production, allowing greater stability and resistance to biotic and abiotic stresses. In France, a Participatory Plant Breeding (PPB) project on bread wheat, involving farmers, facilitators and researchers, has led to the development of heterogeneous populations whose within-variety genetic diversity is expected to confer the ability to adapt to farmers' practices and environments. We studied the stability and local adaptation of ten of these farmers' populations as well as two commercial varieties in relation to their within-variety genetic diversity. Although no clear evidence of local adaptation was detected, we found that populations' grain yield and protein content were more stable over space and time respectively than those of commercial varieties. Moreover, the varieties' stability over time in terms of protein content was positively correlated with within-variety genetic diversity with no significant drawback on protein yield. These results demonstrate the wide adaptive potential of PPB populations, highlighting the importance of seed exchange networks for agrobiodiversity management and use. They emphasize the benefits of genetic diversity for stability over time, which is of great interest to farmers.
\end{abstract}

Keywords: agrobiodiversity; agroecology; decentralized selection; dynamic management; farmers varieties; local adaptation; participatory plant breeding; reciprocal transplant; temporal stability

\section{Introduction}

In recent decades, the increase in inter-annual climate variability has led to instabilities in agricultural production, sometimes leading to food shortages and rises in global food prices $[1,2])$. Projections predict an increase in frequency of extreme low yields due to adverse weather conditions [3,4], since current homogeneous varieties lack resilience to cope with climate instability as was demonstrated for European wheat varieties [5]. Therefore, it is necessary to build sustainable systems that can ensure food security through the stabilization of agricultural production [6].

Agroecology is one of the proposed alternatives to the mainstream system, advocating spatial and temporal diversification to support a sustainable and resilient agriculture based on natural 
regulations [7-10]. One of the identified levers is the increase of genetic diversity at the field level which allows for better disease regulation [11,12], greater resilience to climate variability [13-15], and better ecosystems functioning [16-18]. Increased within-field diversity can be achieved by growing landraces or old varieties (i.e., in the French context, varieties cultivated before 1940 and generally showing some intrinsic genetic variability), by mixing or crossing varieties, and by growing Composite Cross Populations (CPP) or open-pollinated varieties [19]. Intraspecific diversity gives cultivated crops the ability to adapt to change and stabilize production [20,21]. The stabilizing effect is due to complementarity between genotypes exploiting resources from different ecological niches, facilitation, and sampling effects increasing the probability of having a genotype adapted to the conditions [22]. Overyielding and stability effects of variety mixtures were found to increase with components diversity [23,24]; however, no correlation was found with genome-wide genetic diversity for example in oat [25].

Genetic variability for traits involved in responses to environmental conditions is a prerequisite for populations to adapt to their environment. Local adaptation is one of the processes leading to a phenotypic differentiation of populations from the same origin but cultivated in different environments [26]. It can also be defined as the result of this process, a locally adapted population showing a greater fitness in its environment compared to populations from other environments [27]. Local adaptation was widely studied in natural populations using reciprocal transplant experiments [28,29] or common gardens [30]. Specific models are commonly used, as presented by Kawecki and Ebert [27], to study the superiority of resident populations over migrant populations, or the superiority of populations on their farm of origin compared with the same populations grown in other environments [31]. While most studies focused on natural populations, some studies assessing cultivated populations detected local adaptation for example in lentil [32] and common bean [33].

While conventional breeding produces genetically homogeneous varieties, such as pure lines in the case of selfing species, to meet the DUS (Distinction, Uniformity, Stability) requirements for variety registration and Plant Breeder Rights, alternative breeding methods such as decentralized Participatory Plant Breeding (PPB) are being used to develop more diverse varieties better adapted to organic and low-input systems [34]. Decentralized breeding aims at developing varieties adapted to the diversity of environments, taking into account Genotype $\times$ Environment interactions by breeding directly in the target environment $[35,36]$. Varieties can also be adapted to farmers' practices and needs by involving them in the breeding process [37], since they would select varieties with traits relevant to their particular conditions and objectives $[38,39]$. In France a PPB project on bread wheat, involving farmers and facilitators of the Réseau Semences Paysannes (RSP) and researchers from Diversity, Evolution and Adaptation of Populations (DEAP) team of the French National Institute for Agronomic Research (INRA), has been on-going since 2006 with the aim of developing heterogeneous varieties adapted to farmers' practices and needs, and restoring farmers' autonomy in terms of seed selection and management. The project has enabled the development of on-farm breeding tools and methods, such as experimental designs, statistical methods and collective organization between partners [40-42]. New populations have also been created and selected on-farm. Varieties bred in those PPB programs are often heterogeneous because farmers are interested in stability and adaptability to their local conditions. However, adaptation in this case has not been studied so far and although the stability of variety mixtures was demonstrated [43-45], little is known about the stability over time of evolving populations or mixtures derived from PPB, and the potential link to their genetic diversity.

To fill this gap, a two-year experiment was conducted to evaluate ten populations developed within the wheat PPB program, thereafter called PPB populations, compared with two commercial pure line varieties. An agronomic evaluation was carried out (for more information see Goldringer et al., [46]). The design is close to a reciprocal transplant experiment since some of the populations evaluated were tested both on their farm of origin and on other farms. In this study, we assessed the local adaptation of some of the early wheat PPB populations, as well as their genetic 
diversity and spatio-temporal stability compared with the two commercial varieties. Hereafter, the term variety refers to both commercial varieties and $\mathrm{PPB}$ populations, and therefore is not used as in the UPOV definition.

\section{Materials and Methods}

\subsection{Wheat PPB Populations and Commercial Varieties Studied}

Ten wheat populations developed through the PPB project were proposed by five farmers and were evaluated on six farms (CHD, FLM, FRC, JFB, JSG, RAB), along with two commercial varieties (Renan, widely used in France by organic farmers and Hendrix, more recently released and bred for organic agriculture). These ten PPB populations, presented in Table 1, were developed with various methods based on genetically diverse varieties (selection within landraces, cross, mixtures of landraces and/or crosses) and evolved for different durations in their farm of origin. The crosses made in 2006 and subsequent years to generate new populations were based on parental varieties chosen by the farmers involved, and consisted of landraces, old lines and more recent varieties bred for organic farming.

Table 1. Varieties proposed by farmers and their make-up. Varieties included in the local adaptation analysis where the ones originated from the farms setting up the trials $(X)$.

\begin{tabular}{ccccc}
\hline Variety & Farmer & Development Process & Creation Date & $\begin{array}{c}\text { Evaluated } \\
\text { in Their } \\
\text { Farm of Origin }\end{array}$ \\
\hline Saint-Priest & FLM & Derived from a Swedish variety (Progress) & 2004 & X \\
\hline Rouge du Roc & JFB & $\begin{array}{c}\text { Population derived from a mass selection } \\
\text { within a landrace }\end{array}$ & 2001 & $X$ \\
\hline Savoysone & RAB & $\begin{array}{c}\text { Population derived from a cross between } \\
\text { two landraces }\end{array}$ & 2010 & $X$ \\
\hline Pop dynamique 2 & FLM & Mixture of 3 landraces and 2 recent varieties & 2010 & $X$ \\
\hline Mélange du Sud-Ouest & JFB & Mixture of about 18 landraces & early 2000 & X \\
\hline Rocaloex & RAB & Mixture of 11 crosses & 2012 & $X$ \\
\hline Japhabelle & JFB & Mixture of 25 crosses & 2009 & $X$ \\
\hline Dauphibois & CHD & Mixture of 26 landraces and crosses & 2012 & $X$ \\
\hline Mélange 5 bourguignonnes & BER & Mixture of 11 landraces & 2012 & \\
\hline Mélange1 13 pops & BER & Mixture of 13 crosses & 2012 & \\
\hline Renan & INRA & Commercial pure line registered in 1989 & & \\
\hline Hendrix & INRA & Commercial pure line registered in 2013 & & \\
\hline
\end{tabular}

\subsection{Trial Locations}

Trials were conducted during two growing seasons (2013-2014 and 2014-2015) in several locations in France, on four of the five farms from which the populations originated (CHD, Isère (38); FLM, Maine-et-Loire (49); JFB, Lot-et-Garonne (47); and RAB, Haute-Savoie (74)), and two other farms (JSG, Puy-de-Dôme (63); and FRC, Gard (30)). These farms presented different pedo-climatic conditions (Table 2 and Supplementary Material S1). Some farms presented deep and fertile soils (JSG and RAB) while others had very superficial soils (FRC, CHD). Moreover, one farm in southern France is located in a very dry and hot area (FRC) while CHD, RAB and JSG farms have colder temperatures during winter. Trials were managed by each farmer according to their own practices under organic management. The experimental design was a complete randomized block design with 2 replicates except in JSG farm in which 3 replicates were sown, and plots size ranged between 7 and $120 \mathrm{~m}^{2}$. 
Table 2. Trials information.

\begin{tabular}{cccccc}
\hline Farm & Growing Season & Soil Type & Sowing Date & Sowing Density & Plot Size \\
\hline CHD & $2013-2014$ & Clay-limestone & 13 November 2013 & $300 \mathrm{grains} / \mathrm{m}^{2}$ & $22.5 \mathrm{~m}^{2}$ \\
CHD & $2014-2015$ & Clay-limestone & 29 October 2014 & $300 \mathrm{grains} / \mathrm{m}^{2}$ & $10 \mathrm{~m}^{2}$ \\
FLM & $2013-2014$ & Sandy hydromorphic & 27 November 2013 & $300 \mathrm{grains} / \mathrm{m}^{2}$ & $10 \mathrm{~m}^{2}$ \\
FLM & $2014-2015$ & Sandy hydromorphic & November 2014 & $300 \mathrm{grains} / \mathrm{m}^{2}$ & $10 \mathrm{~m}^{2}$ \\
FRC & $2013-2014$ & Clay-limestone dry & 1 November 2013 & $23 \mathrm{~g} / \mathrm{m}^{2}$ & $10 \mathrm{~m}^{2}$ \\
FRC & $2014-2015$ & Clay-limestone dry & 18 December 2014 & $250 \mathrm{grains} / \mathrm{m}^{2}$ & $10 \mathrm{~m}^{2}$ \\
JFB & $2013-2014$ & Clay-limestone & 12 December 2013 & $12.5 \mathrm{~g} / \mathrm{m}^{2}$ & $8 \mathrm{~m}^{2}$ \\
JFB & $2014-2015$ & Clay-limestone & 13 November 2014 & & $10 \mathrm{~m}^{2}$ \\
JSG & $2013-2014$ & Clay-limestone & 27 November 2013 & $350 \mathrm{grains} / \mathrm{m}^{2}$ & $7 \mathrm{~m}^{2}$ \\
JSG & $2014-2015$ & Clay-limestone & 31 October 2014 & $350 \mathrm{grains} / \mathrm{m}^{2}$ & $7.8 \mathrm{~m}^{2}$ \\
RAB & $2013-2014$ & Loam & 2 November 2013 & $20 \mathrm{~g} / \mathrm{m}^{2}$ & $22.5 \mathrm{~m}^{2}$ \\
RAB & $2014-2015$ & Clay-loam & 29 October 2014 & $15 \mathrm{~g} / \mathrm{m}^{2}$ & $120 \mathrm{~m}^{2}$ \\
\hline
\end{tabular}

\subsection{Measured Traits}

Several characters were measured at the plot level: thousand kernel weight (TKW, determined on $20 \mathrm{~g}$ of cleaned seed samples per plot), grain yield (GY, in qx/ha) and protein content (PC, in \% of protein in the grain measured with NIRS technology at INRA Clermont Ferrand France on grain using near infrared spectroscopy (FOSS NIRSystem 6500)). Others traits were measured on individual plants sampled randomly (25 plants per plot) such as plant height $(\mathrm{PH})$, spike weight ( $\mathrm{SW}$, measured on spikes after harvest, moisture under 15\%) and length (SL), last leaf to spike distance (LLSD, corresponding to the peduncle length), number of spikelets per spike (NSPK), proportion of sterile spikelets (NSPK_st, which are small spikelets at the bottom and top of the spike that do not contain seeds), and spikes morphological characters (colour, presence of awns and curve). These last three traits were determined by using visual scales from 0 to 20 (possible values were $0,5,10,15$ and 20). For colour the scale ranged from white to dark red. For the presence of awns it went from no awns to abundant and long awns all along the spike. Curve was measured as the angle between the spike and the straw, from no curve to a $180^{\circ}$ angle.

\subsection{Genotypic Data}

Ninety plants per population were sampled on five farms in 2015 (eighteen per farm) for PPB populations and thirty plants per commercial variety (six per farm). The seeds were sown at Le Moulon experimental station in autumn 2015 and a piece of leaf was collected from each seedling at the 2-leaf stage for genotyping. For each plant, total DNA was extracted from $200 \mathrm{mg}$ of young leaves, using 96 well plate Whatman unifilter 800 GF/B (Whatman Ref 7700-2803) and following a protocol derived from the Qiagen's DNeasy 96 Plant Kit (Qiagen, Basel, Switzerland). 86 markers using the KASP ${ }^{\mathrm{TM}}$ method (LGC Biosearch Technologies) [47] were assessed, including 52 in non coding region of the genome (neutral zones) and 34 in candidate genes for heading precocity. These markers are presented in Appendix B. The analyses were done on polymorphic markers: 50 for neutral ones and 30 for markers in candidate genes.

\subsection{Genetic Diversity}

All the analysis were carried out using R software [48], and the genetic analysis using adegenet package [49]. Euclidian distances (Roger's distance) between varieties were calculated and a clustering was done using the Ward method. Within-variety diversity was assessed by computing the expected $\mathrm{(He}$ ) and observed $\mathrm{(Ho}$ ) heterozygosity. The former was estimated as the Nei diversity index based on the allelic frequencies at each locus [50], and the latter was estimated as the proportion of heterozygous individuals at each locus averaged over all loci that were polymorphic within the studied variety. 


\subsection{Local Adaptation}

Local adaptation is frequently studied in ecological experiments on natural populations using translocation experiments, in which populations from different origins are sown both in their environment of origin and in other environments. Specific models are used to characterize (i) the superiority of residents over migrants in their home environment ("Local vs. Foreign") and (ii) the superiority of populations when grown in their home environment compared to other environments ("Home vs. Away") [27]. These models, which were implemented in the PPBstats package [51], were applied to a subset of the agronomic data which included PPB populations evaluated on their farm of origin (all PPB populations except Mélange1 13 pops and Mélange 5 bourguignonnes, see Table 1), and trials conducted on farms where the populations were developed (FLM, JFB, RAB and CHD).

\subsubsection{Local vs. Foreign}

The model used to detect a superiority of residents in their farm of origin compared to populations coming from other farms was the following type III ANOVA:

$$
\begin{aligned}
Y_{i j k l m} & =\mu+\text { pop }_{i}+\text { farm }_{j}+\text { year }_{l}+M R_{i j}+(\text { farm } \times \text { year })_{j l}+(M R \times \text { farm })_{i j} \\
& +\operatorname{rep}(\text { farm } \times \text { year })_{k j l}+(M R \times \text { farm } \times \text { year })_{i j l}+R_{i j k l m}
\end{aligned}
$$

with $Y_{i j k l m}$ the phenotypic value of population $i$ in farm $j$, replicate $k$, year $l$, and individual $m$ for variables measured at the individual level, pop $p_{i}$ the effect of population $i$, farm $_{j}$ the effect of the farm $j$, year $r_{l}$ the effect of year $l, M R_{i j}$ the status (Migrant or Resident) of population $i$ in farm $j$, and $R_{i j k l m}$ the residual.

The comparison of values for all populations in sympatry vs. allopatry situation is characterized by the $M R$ effect that gives a global measure of local adaptation [31]. The $(M R \times f a r m)_{i j}$ interaction term provides information on adaptation patterns specific to each farm, while the triple interaction effect detects if this adaptation is specific to the year.

\subsubsection{Home vs. Away}

The model used to detect a superiority of populations grown on their farm of origin compared with the same populations cultivated on other farms was the following type III ANOVA:

$$
\begin{aligned}
Y_{i j k l m} & =\mu+\text { pop }_{i}+\text { farm }_{j}+\text { year }_{l}+M R_{i j}+(\text { farm } \times \text { year })_{j l}+(M R \times p o p)_{i j} \\
& +\operatorname{rep}(\text { farm } \times \text { year })_{k j l}+(M R \times \text { pop } \times \text { year })_{i j l}+R_{i j k l m}
\end{aligned}
$$

with $Y_{i j k l m}$ the phenotypic value of population $i$ in farm $j$, replicate $k$, year $l$, and individual $m$ for variables measured at the individual level, pop $p_{i}$ the effect of population $i$, farm $_{j}$ the effect of the farm $j$, year $r_{l}$ the effect of year $l, M R_{i j}$ the status (Migrant or Resident) of population $i$ in farm $j$, and $R_{i j k l m}$ the residual.

As in model 1, the $M R$ effect tests for a global local adaptation of populations to their original farm. Here the interaction term $(M R \times p o p)_{i j}$ provides information on adaptation patterns specific to each population, while the triple interaction effect detects if this adaptation is specific to the year.

\subsection{Temporal Stability}

To study varieties' stability over years in a given farm, the following model was applied to each variable and variety:

$$
Y_{i j k l}=\text { Year }_{i}+\text { Farm }_{j}+(\text { Farm } \times \text { Year })_{i j}+\epsilon_{i j k l}
$$

with $Y_{i j k l}$ the phenotypic value of the studied variety, Year ${ }_{i}$ the effect of year $i$, Farm $_{j}$ the effect of farm $j,(\text { Farm } \times \text { Year })_{i j}$ the interaction effect of year $i$ and farm $j, k$ is the replicate, $l$ is the individual plant 
for variables measured at the individual level, and $\epsilon_{i j k l}$ is the residual. All effects were considered random and therefore variances associated with the effects were estimated using the REML procedure.

For each variety and each effect (Year, Farm, Farm $\times$ Year and the residual) a coefficient of variation was calculated as the standard deviation associated with the effect divided by the mean of the variety across all farms and years. These coefficients of variation were used to compare the variation due to each effect between varieties. Stability over years in a given farm was characterized by the sum of the Year and (Farm $\times$ Year) coefficients of variation, while the Residual coefficient of variation was used to characterize the phenotypic variability of a variety for traits measured at the individual level. Mean comparisons between PPB populations and commercial varieties stability was done using the Mann-Whitney test. Correlation coefficients were then calculated between genetic diversity $(\mathrm{He})$, phenotypic variability (either for each trait measured at the individual level or for an index calculated as the mean of the coefficients of variation of each trait measured at the individual level, the latter used to represent the overall heterogeneity of the variety) and stability (taken here as $(-1) \times$ coefficient of variation associated with the Year and (Farm $\times$ Year) effects).

\subsection{The Participatory Dimension}

Researchers, farmers and facilitators involved in the PPB project meet regularly between field visits, usually during winter when farmers have more time, to discuss ongoing research projects, new results and perspectives. At a meeting in winter 2015-2016, the raw results were first presented to farmers and facilitators and the discussion led to ideas for further analysis and testing of the data set. Farmers were particularly interested in the temporal stability of the different varieties and its possible link with genetic diversity and intravarietal phenotypic diversity. The results of the new analyses were then presented at a meeting a few months later, which allowed for discussion and a common understanding of the new results. This is what is presented here.

\section{Results}

\subsection{Genetic Diversity}

\subsubsection{Genetic Distances between Varieties}

The two commercial varieties appeared clearly distinct from the PPB populations grouped together, as shown in Figure 1. Some of the PPB populations appeared quite similar, probably because these mixtures have common components. For example, Mélange1-13 pops, Dauphibois, Rocaloex and Japhabelle mixtures are partly composed of the same crosses whose parents were mixed in Mélange-du-Sud-Ouest population. One of Savoysone's parents (Blanc de Saône) is very close genetically to three of Mélange-5-Bourguignonnes' landrace components (Blé de la Saône, Blanc hâtif de la Saône and Blanc de haute Saône), which may explain the genetic proximity of these two PPB populations.

\subsubsection{Within-Variety Genetic Diversity}

As expected, pure line commercial varieties exhibited low to no genetic diversity, while PPB populations with the highest level of diversity were mixtures (Table 3). Hendrix showed a little genetic diversity, which was due to one individual that exhibited differences for three markers in neutral zones. This punctual diversity is most probably due to a residual variability within the variety.

$\mathrm{He}$ was lower for markers in candidate genes (CA) than in neutral zones (NE), and the ranking of populations was not the same, meaning that these populations were under different levels of selection pressure on these zones of the genome. Savoysone, a population derived from a cross between two landraces, proved to be as diverse as Mélange-5-Bourguignonnes, a mixture of landraces, when looking at $H e_{\mathrm{NE}}$. This population also exhibited more heterozygous individuals than all other varieties for $\mathrm{NE}$ and CA markers ( 0.011 and 0.010 respectively), probably due to the fact that the cross was made more 
recently than those of Mélange1 13 pops, Rocaloex, Japhabelle and Dauphibois that were created in 2006, and was probably still segregating.

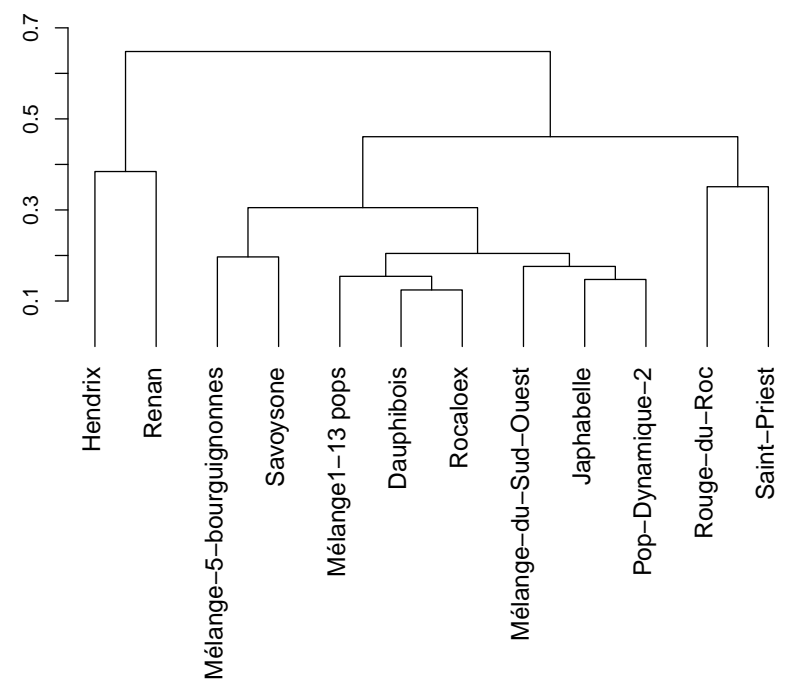

Figure 1. Clustering of the PPB populations and the two commercial pure lines on the Rogers' distances using the Ward clustering method. The length of the branches represent the distance between two varieties.

Table 3. Expected heterozygosity $(\mathrm{He})$ and observed heterozygosity $(\mathrm{Ho})$ of each variety for neutral markers (NE) and markers in candidate genes (CA). "-" means all locus were monomorphic for the variety.

\begin{tabular}{rccccc}
\hline \multirow{2}{*}{ Population } & \multirow{2}{*}{ Number of Individuals } & \multicolumn{2}{c}{ He } & \multicolumn{2}{c}{ Ho } \\
\cline { 3 - 6 } & & NE & CA & NE & CA \\
\hline Renan & 30 & 0.000 & 0.000 & - & - \\
Hendrix & 29 & 0.004 & 0.000 & 0.000 & 0.000 \\
Rouge-du-Roc & 90 & 0.084 & 0.062 & 0.001 & 0.000 \\
Saint-Priest & 90 & 0.129 & 0.081 & 0.005 & 0.007 \\
Mélange-5-bourguignonnes & 90 & 0.283 & 0.128 & 0.010 & 0.004 \\
Savoysone & 90 & 0.290 & 0.109 & 0.011 & 0.010 \\
Pop-Dynamique-2 & 90 & 0.361 & 0.205 & 0.006 & 0.006 \\
Mélange-du-Sud-Ouest & 90 & 0.363 & 0.233 & 0.010 & 0.009 \\
Rocaloex & 90 & 0.377 & 0.157 & 0.002 & 0.001 \\
Japhabelle & 90 & 0.388 & 0.146 & 0.008 & 0.004 \\
Mélange1-13 pops & 90 & 0.396 & 0.150 & 0.007 & 0.002 \\
Dauphibois & 90 & 0.402 & 0.198 & 0.004 & 0.002 \\
\hline
\end{tabular}

\subsubsection{Correlations between Genetic Diversity and Phenotypic Variability}

For most traits the correlation between phenotypic variability, estimated as the residual coefficient of variation in eq.3, and genetic diversity, both for NE and CA markers, was high and significant, except for SW, NSPK_st and to a lesser extent curve, for which commercial varieties seemed to be as variable as PPB populations (Table 4). This has already been observed in another study [52], in which the phenotypic variance of commercial varieties for spike weight and non morphological traits was large, which showed the sensitivity of these varieties to environmental heterogeneity. The correlations between mean traits variability and $\mathrm{He} e_{\mathrm{NE}}(0.699, p=0.011)$ on the one hand, and $\mathrm{He}_{\mathrm{CA}}(0.607, p=0.036)$ on the other hand, were also highly positive and significant.

Finally, there were rather high correlations between varieties' genetic diversity and their average trait value for PH (NE: 0.71, $p=0.010$; CA: 0.73, $p=0.0072$ ), which was due to the fact that the two 
homogeneous commercial varieties were also the shortest. For all other traits, there was no correlation between genetic diversity and average trait value.

Table 4. Correlation between phenotypic variability estimated as the residual coefficient of variation (eq. 3) and genetic diversity for neutral markers (NE) and markers in candidate genes (CA) for the 12 varieties for variables measured at the individual level. Bold: significant at 5\%, Italic: significant at $10 \%$. PH: plant height; LLSD: last leaf to spike distance; SL: spike length; SW: spike weight; NSPK: number of spikelets per spike; NSPK_st: proportion of sterile kernels.

\begin{tabular}{rcc}
\hline & NE & CA \\
\hline PH & $\mathbf{0 . 8 6 2}$ & $\mathbf{0 . 8 1 5}$ \\
LLSD & $\mathbf{0 . 8 3 2}$ & $\mathbf{0 . 8 9 1}$ \\
awns & $\mathbf{0 . 8 7 6}$ & $\mathbf{0 . 8 6 9}$ \\
color & $\mathbf{0 . 8 6 5}$ & $\mathbf{0 . 7 7 3}$ \\
curve & 0.556 & 0.507 \\
SL & $\mathbf{0 . 7 1 7}$ & $\mathbf{0 . 5 8 0}$ \\
SW & -0.243 & -0.235 \\
NSPK & $\mathbf{0 . 8 1 4}$ & $\mathbf{0 . 7 1 6}$ \\
NSPK_st & 0.355 & 0.203 \\
\hline
\end{tabular}

\subsection{Local Adaptation}

Tables 5 and 6 present the ANOVA results for all characters. Information on mean and standard error of each variety for each farm and year is available in Supplementary Material S2. The MR effect was significant for all characters except GN, either as main effect or involved in interactions with other factors: SL, SW, NSPK_st and PC for both models (Tables 5 and 6) and NSPK, TKW and GY only in the Home vs Away model (Table 5).

Table 5. ANOVA results of the Local vs. Foreign analysis: spike length (SL); spike weight (SW); number of spikelets per spike (NSPK); proportion of sterile kernels (NSPK_st); thousand kernel weight (TKW); protein content (PC); number of grains per $\mathrm{m}^{2}(\mathrm{GN})$; grain yield (GY). ${ }^{* * *} p<0.001 ;{ }^{* *} p<0.01$; ${ }^{*} p<0.05{ }^{a}$ : individual data; ${ }^{b}$ : plot data.

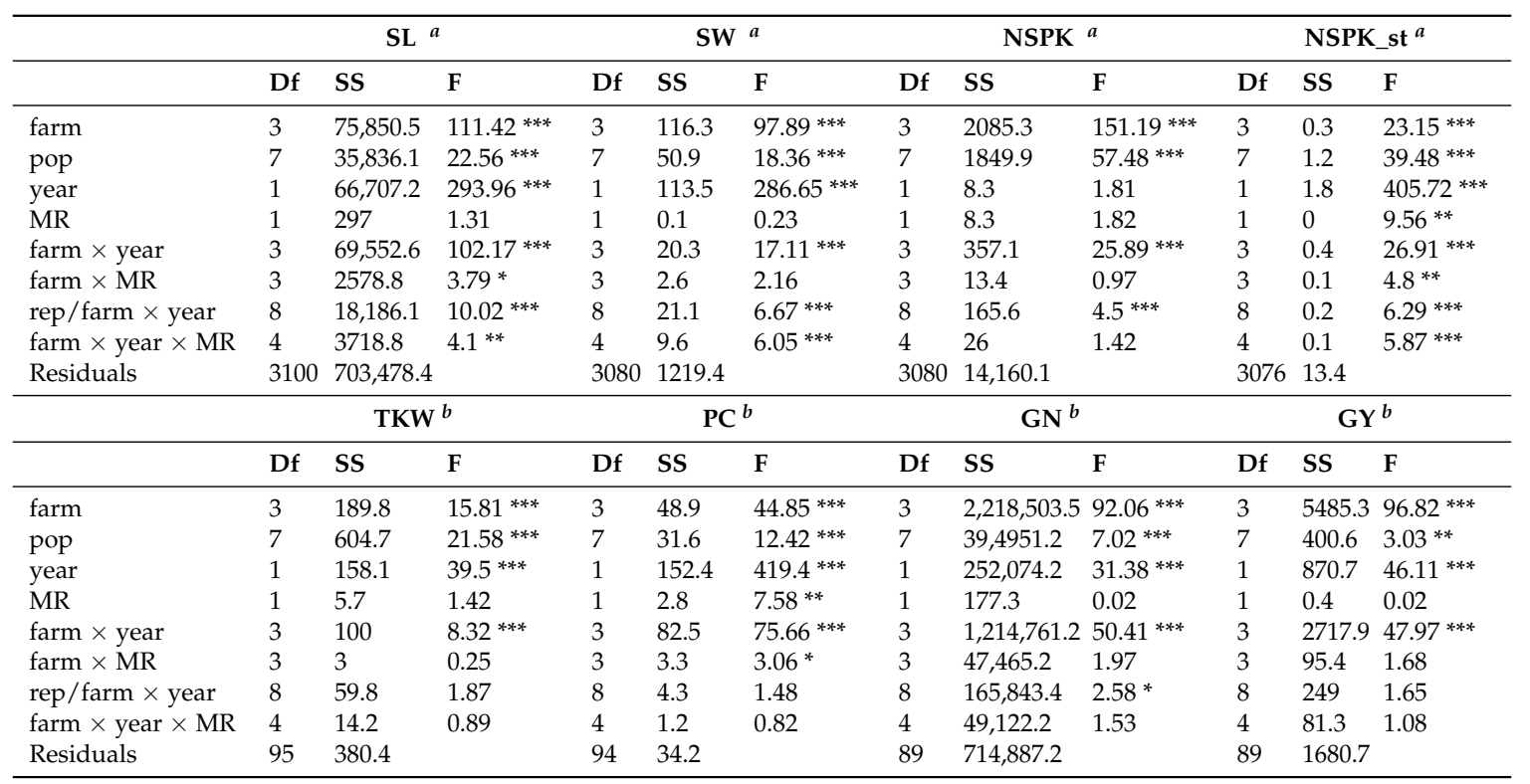

Migrants exhibited significantly higher PC than residents only in two farms and for two populations (Figure 2). For all other characters the results were contrasted with either migrants or residents showing superiority depending on the farm or population. While residents exhibited a higher NSPK_st in RAB farm for both years, results in FLM farm showed opposite effect regarding MR 
status depending on the year (Figure 3a). Moreover, only the two populations developed in RAB farm presented a higher NSPK_st for both years (Savoysone and Rocaloex), while for other populations the differences were either insignificant or inconsistent from one year to the next (Figure 3b). For SW (Figure 4), the superiority of residents over migrants depended on the farm, the year and the population, with no consistent trend, except that on JFB's farm the resident populations had a larger SW, and that two JFB's populations (Japhabelle and Rouge du Roc) showed a significantly larger SW on their farm of origin. Finally, Rouge du Roc exhibited a lower PC at home than in foreign environments, which could be explained by a dilution effect since this population also presented a higher SW at home.

Table 6. ANOVA results of the Home vs. Away analysis: spike length (SL); spike weight (SW); number of spikelets per spike (NSPK); proportion of sterile kernels (NSPK_st); thousand kernel weight (TKW); protein content (PC); number of grains per $\mathrm{m}^{2}$ (GN); grain yield (GY). ${ }^{* * *} p<0.001$; ${ }^{* *} p<0.01$; ${ }^{*} p<0.05{ }^{a}$ : individual data; ${ }^{b}$ : plot data.

\begin{tabular}{|c|c|c|c|c|c|c|c|c|c|c|c|c|}
\hline & \multicolumn{3}{|c|}{$\mathrm{SL}^{a}$} & \multicolumn{3}{|c|}{$\mathrm{SW}^{a}$} & \multicolumn{3}{|c|}{ NSPK ${ }^{a}$} & \multicolumn{3}{|c|}{ NSPK_st ${ }^{a}$} \\
\hline farm & 3 & $75,850.5$ & $112.65^{* * *}$ & 3 & 116.3 & $101.03^{* * *}$ & 3 & 2085.3 & $151.94^{* * *}$ & 3 & 0.3 & $23.52 * * *$ \\
\hline year & 1 & $66,707.2$ & $297.21^{* * *}$ & 1 & 113.5 & $295.84^{* * *}$ & 1 & 8.3 & 1.81 & 1 & 1.8 & $412.1^{* * *}$ \\
\hline MR & 1 & 297 & 1.32 & 1 & 0.1 & 0.24 & 1 & 8.3 & 1.82 & 1 & 0 & $9.71 * *$ \\
\hline farm $\times$ year & 3 & $69,552.6$ & $103.29 * * *$ & 3 & 20.3 & $17.66^{* * *}$ & 3 & 357.1 & $26.02 * * *$ & 3 & 0.4 & $27.33^{* * *}$ \\
\hline pop $\times$ year $\times$ MR & 15 & $12,269.9$ & $3.64^{* * *}$ & 15 & 40.4 & $7.02 * * *$ & 15 & 118.5 & $1.73 *$ & 15 & 0.3 & $5.03 * * *$ \\
\hline \multirow[t]{3}{*}{ Residuals } & 3085 & $692,420.7$ & & 3065 & 1175.8 & & 3065 & $14,021.4$ & & 3061 & 13.1 & \\
\hline & \multicolumn{3}{|c|}{$\mathrm{TKW}^{b}$} & \multicolumn{3}{|c|}{$\mathrm{PC}^{b}$} & \multicolumn{3}{|c|}{$\mathrm{GN}^{b}$} & \multicolumn{3}{|c|}{$\mathrm{GY}^{b}$} \\
\hline & Df & SS & $\mathbf{F}$ & Df & SS & $\mathbf{F}$ & Df & SS & $\mathbf{F}$ & Df & SS & $\mathbf{F}$ \\
\hline farm $\times$ year & 3 & 100 & $9.4^{* * *}$ & 3 & 82.5 & $76.38^{* * *}$ & 3 & $1,214,761.2$ & $53.07^{* * *}$ & 3 & 2717.9 & $55.13^{* * *}$ \\
\hline pop $\times$ MR & 7 & 7.8 & 0.31 & 7 & 6.2 & $2.47 *$ & 7 & $70,444.7$ & 1.32 & 7 & 170.9 & 1.49 \\
\hline rep/farm $\times$ year & 8 & 59.8 & $2.11 *$ & 8 & 4.3 & 1.5 & 8 & $166,093.2$ & $2.72 *$ & 8 & 248.9 & 1.89 \\
\hline pop $\times$ year $\times$ MR & 15 & 106.2 & $2 *$ & 15 & 4 & 0.75 & 15 & $176,163.7$ & 1.54 & 15 & 470.7 & $1.91 *$ \\
\hline Residuals & 80 & 283.6 & & 79 & 28.4 & & 74 & $564,616.3$ & & 74 & 1216 & \\
\hline
\end{tabular}

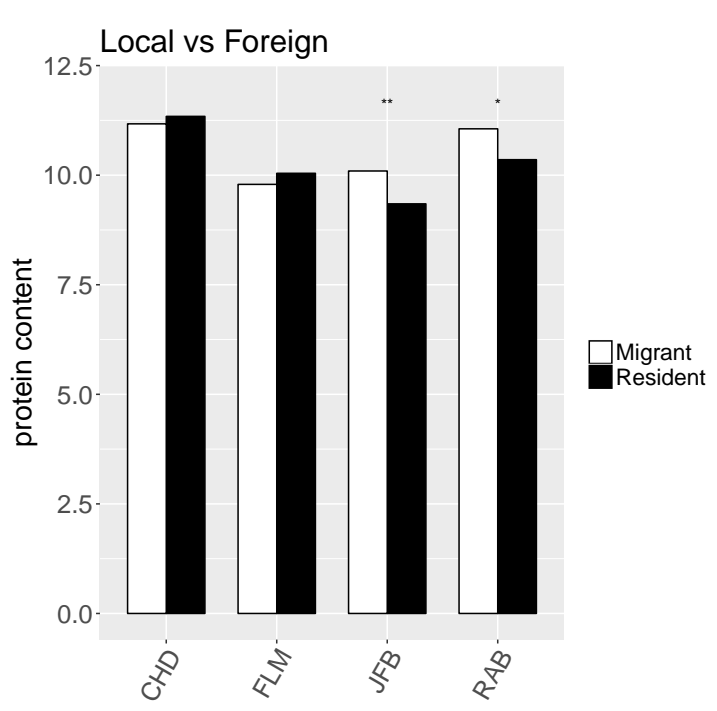

(a)

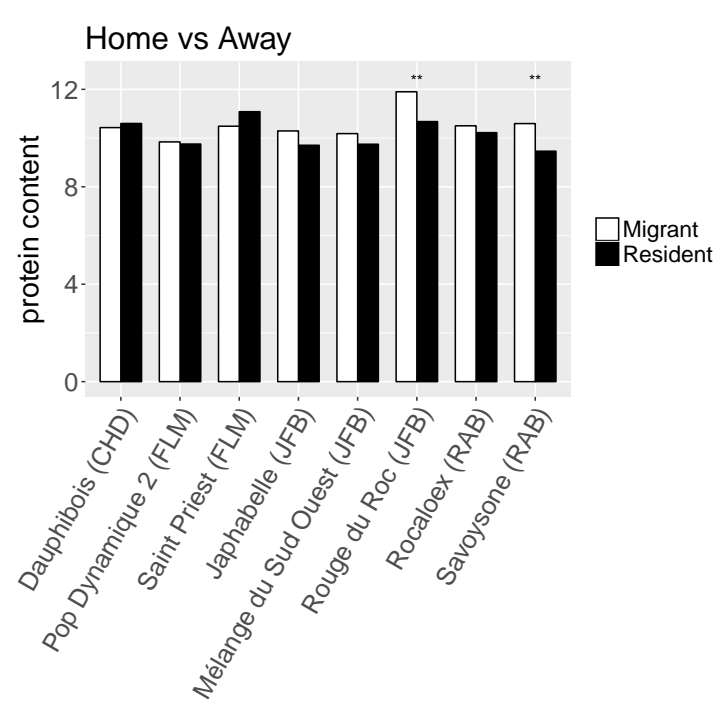

(b)

Figure 2. Least-square means for the interaction effects between "migrant vs resident" status and (a) farm ("Local vs Foreign") or (b) population origin ("Home vs Away", the farm of origin of each population is indicated in brackets) for protein content (PC). 


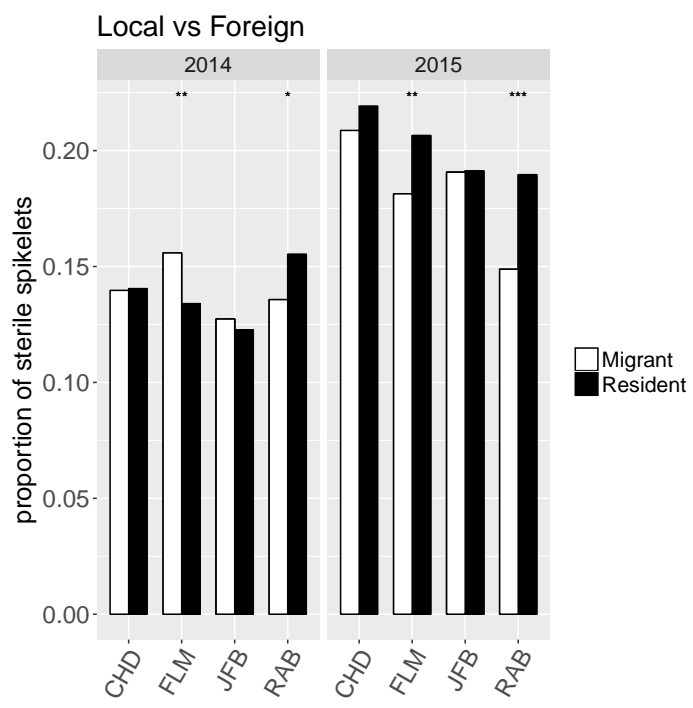

(a)

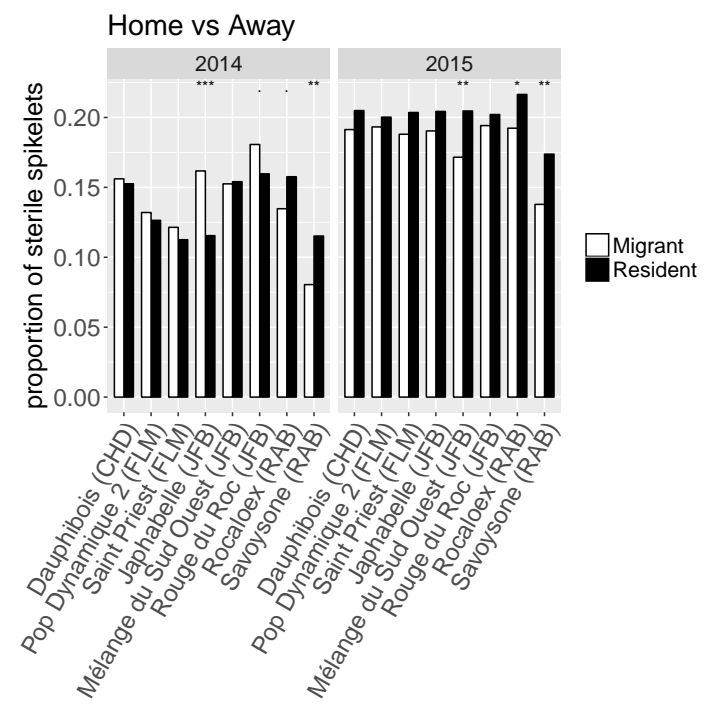

(b)

Figure 3. Least-square means for the interaction effects between "migrant vs resident" status and (a) farm ("Local vs Foreign") or (b) population origin ("Home vs Away", the farm of origin of each population is indicated in brackets) for the proportion of sterile kernels (NSPK_st).

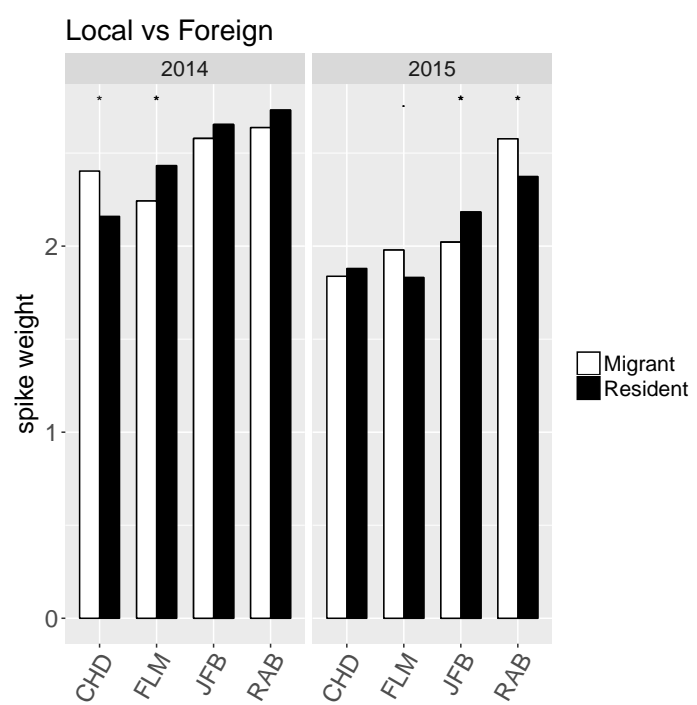

(a)

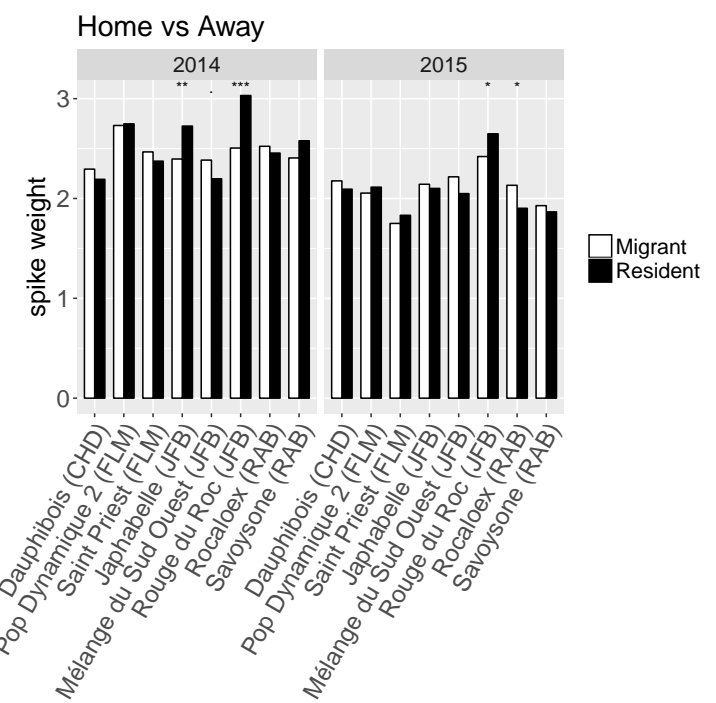

(b)

Figure 4. Least-square means for the interaction effects between "migrant vs resident" status and (a) farm ("Local vs Foreign") or (b) population origin ("Home vs Away", the farm of origin of each population is indicated in brackets) for spike weight (SW).

\subsection{Spatio-Temporal Stability and Its Link with Genetic and Phenotypic Variability}

\subsubsection{Spatio-Temporal Stability}

Stability over time within a farm can be characterized for each trait by the sum of the Year and $($ Farm $\times$ Year $)$ coefficients of variation. Table 7 shows, for each variety, characters for which the variability explained by at least one effect is higher than that of the residuals (which correspond to the intra-environment variability). The results for the other traits are presented in Appendix A. The average temporal stabilities of PPB populations and commercial varieties were close for PH $(0.113$ and 0.132 respectively) and TKW (resp. 0.050 and 0.052 ). However, PPB populations were more stable over time than commercial varieties for PC (resp. 0.238 and $0.346, p=0.030$ ) and tended to be more 
stable for GN (resp. 0.256 and 0.330, $p=0.27$ ) and GY (resp. 0.284 and $0.353, p=0.27$ ) although not significantly. Considering stability across farms, only GN and GY showed significant differences as commercial varieties were more strongly varying than PPB populations (resp. 0.368 and 0.218 , $p=0.030$ for GN and 0.366 and $0.228, p=0.030$ for GY). These two traits presented similar patterns of responses to all effects, which indicates that yield stability was probably mainly due to stability in grain number setting and therefore a stability in tillering capacity. We noticed that for PC none of the variety types (PPB or commercial) were sensitive to the Farm effect. Variability due to intra-environment heterogeneity (Residuals) was sometimes higher for commercial varieties than for PPB populations (GY, GN, LLSD, SW, NSPK_st, see Appendix A), but it was only marginally significant for LLSD and GY $(p=0.06)$.

Table 7. Coefficients of variation for each effect. Y: Year; F: Farm; FY: Farm $\times$ Year interaction; Res: Residual. PPB: PPB populations; CV: Commercial varieties. Bold: significant at 5\%, Italic: significant at $10 \%$. ${ }^{a}$ : individual data; ${ }^{b}$ : plot data. PH: plant height; TKW: thousand kernel weight; PC: protein content; $\mathrm{GN}$ : number of grains per $\mathrm{m}^{2}$; $\mathrm{GY}$ : grain yield.

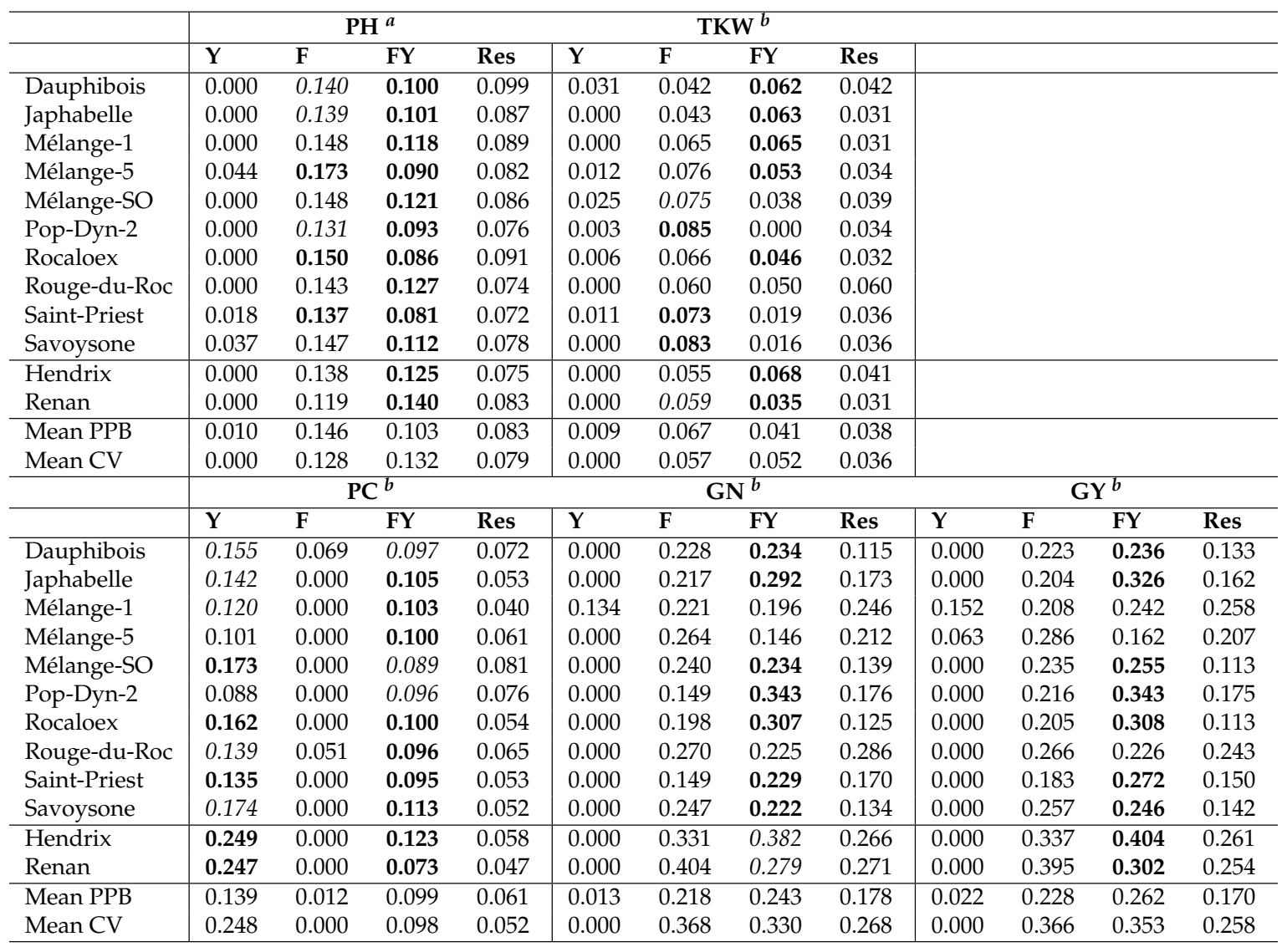

\subsubsection{Correlations between Diversity and Stability}

For most traits, stability over time was not significantly correlated with neutral genetic diversity (Table 8), except for PC with a correlation between temporal stability and $\mathrm{He}_{\mathrm{NE}}$ of $0.582(p=0.047)$. This correlation was even greater when considering markers located in candidate genes for precocity: $0.632(p=0.028)$. This greater temporal stability for PC was not linked to a lower variety effect in protein production since the correlation was $0.384(p=0.218)$. Although there was a trend towards greater temporal stability of PC associated with higher mean phenotypic variability, the correlation was not significant $(0.483, p=0.11)$. There were negative but moderate correlations between temporal stability and variety effect for GN $(-0.581, p=0.048)$ and GY $(-0.537, p=0.072)$, which makes it possible to identify PPB populations that present a good trade-off between productivity and temporal stability. 
Considering stability across farms, only three traits presented significant correlations between stability and genetic diversity: NSPK (NE: $-0.578, p=0.049$ ), GN (NE: 0.646, $p=0.023$; CA: 0.678, $p=0.015$ ) and GY (NE: 0.730, $p=0.007$; CA: 0.711, $p=0.0095$ ). This greater stability in GY and GN linked to a higher genetic diversity is very interesting considering the fact that this stability is not correlated with a lower variety effect $(-0.152, p=0.638$ for GN; $-0.435, p=0.157$ for GY). For NSPK the differences in stability between varieties were very small (Table A1), so this correlation probably has little biological significance.

Table 8. Correlation between temporal and spatial stability (-cv) and genetic diversity $\left(H e_{\mathrm{NE}}\right)$, and between temporal and spatial stability and variety effect. PH: plant height; LLSD: last leaf to spike distance; SL: spike length; SW: spike weight; NSPK: number of spikelets per spike; NSPK_st: proportion of sterile kernels; TKW: thousand kernel weight; PC: protein content; GN: number of grains per $\mathrm{m}^{2}$; GY: grain yield. Bold: significant at $5 \%$, Italic: significant at $10 \%$.

\begin{tabular}{rcccccc}
\hline \multicolumn{3}{c}{ Temporal } & \multicolumn{3}{c}{ Spatial } \\
\hline & \multicolumn{2}{c}{ Diversity } & Variety Effect & \multicolumn{2}{c}{ Diversity } & Variety Effect \\
\hline NE & CA & & NE & CA \\
\hline PH & 0.455 & 0.487 & 0.233 & -0.408 & -0.337 & -0.568 \\
LLSD & -0.185 & -0.147 & $-\mathbf{0 . 7 7 0}$ & -0.270 & -0.143 & -0.242 \\
SL & 0.222 & 0.287 & 0.135 & -0.049 & -0.069 & 0.503 \\
SW & 0.374 & 0.444 & 0.136 & 0.302 & 0.260 & 0.153 \\
NSPK & 0.480 & 0.361 & 0.475 & $-\mathbf{0 . 5 7 8}$ & -0.426 & -0.342 \\
NSPK_st & 0.300 & 0.427 & $\mathbf{0 . 7 7 5}$ & 0.135 & -0.033 & -0.290 \\
TKW & -0.182 & -0.124 & -0.062 & -0.068 & -0.187 & 0.194 \\
PC & $\mathbf{0 . 5 8 2}$ & $\mathbf{0 . 6 3 2}$ & 0.384 & -0.033 & -0.111 & -0.425 \\
GN & 0.072 & 0.140 & $-\mathbf{0 . 5 8 1}$ & $\mathbf{0 . 6 4 6}$ & $\mathbf{0 . 6 7 8}$ & -0.152 \\
GY & 0.060 & 0.190 & -0.537 & $\mathbf{0 . 7 3 0}$ & $\mathbf{0 . 7 1 1}$ & -0.435 \\
\hline
\end{tabular}

\section{Discussion}

\subsection{Genetic and Phenotypic Diversity}

Populations developed through the French wheat PPB programme were diverse with different levels of genetic diversity, which corroborates the fact that PPB programs usually lead to the development of a wide diversity of varieties [53]. On the contrary, commercial varieties were genetically homogeneous as expected. These different levels of genetic diversity in PPB populations reflect their history and farmers' practices, as the most diversified mixtures in terms of number and type of components also had larger within-variety genetic diversity.

Since phenotypic variability estimated on the basis of the residual coefficient of variation is influenced by the means of the traits, it is difficult to compare commercial varieties with PPB varieties for PH and LLSD based on the coefficient of variation because the mean values for Renan and Hendrix are much lower. Visually, plots of commercial varieties appeared more homogeneous for $\mathrm{PH}$ and LLSD which makes the identification of potential off-types easier during fixation or multiplication. For the other traits, phenotypic variability measured on individual plants was not necessarily lower for commercial pure lines than for PPB varieties under organic conditions despite the strict evaluation for homogeneity they undergo for the registration to the official catalogue. This is in line with the findings of Serpolay et al., [52], and highlights the sensitivity of these commercial varieties to heterogeneous conditions, as organic farming is characterized by environmental heterogeneity.

\subsection{Detection of Local Adaptation}

Decentralized selection is based on the fact that varieties bred in a specific environment will adapt to this environment, under the effect of both human and natural selection. As such, local adaptation is expected in these populations selected on-farm. However, although genetic $[54,55]$ 
and phenotypic (plant height, earliness [56,57]) differentiation between populations evolving in contrasted environments were already demonstrated [58,59], our analysis did not detect general local adaptation patterns on these PPB varieties. Several factors could explain these results.

First of all, the experimental design was not optimized to study local adaptation as the varieties used were of very diverse origins (an old variety, a selection of a plant within a landrace, a cross and several mixtures) with a wide range of within-variety genetic diversity, and were selected and cultivated for contrasting numbers of years on their original farms. The most recent ones might not have had enough time to adapt to their environment. This is inherent of participatory research where a compromise has to be found between farmers' wishes and the experimental design format. The population that showed the strongest sign of local adaptation for spike weight was Rouge du Roc, the population that was cultivated the longest in its farm of origin.

Secondly, here only the farm effect was studied. However, agricultural systems are different from natural ones. We can expect cultivated populations to adapt not only to pedo-climatic conditions but also to farmers' practices that were not taken into account in this analysis. Although the environments had contrasted soil and climate characteristics, these characteristics and farmers' practices may not have been sufficiently contrasted to detect local adaptation, which is better detected at large spatial scales [60]. It is also possible that climatic variability tempered local adaptation if this variability was larger than spatial variability between environments [30].

Farmers select their populations based on an overall assessment of their behaviour or a combination of traits, rather than on individual traits. Although grain yield is of importance to farmers and summarizes the global vigor of the population, it might not always be the primary trait farmers select for, and trade-off between traits may have limited their maximization. Moreover, depending on their context and their objectives, farmers have different selection targets (yield, quality, resistance to lodging, morphological characteristics, ...) and selection practices, so that populations will not evolve the same way under farmers' selection. Another study assessing local adaptation of wheat landraces using different kinds of design and models [61] found that varieties in different farms evolved inconsistently across farms, and not necessarily towards an improvement of agronomic performance. Finally, the analysis was done on traits associated with but not directly corresponding to fitness, and these traits may not be the most relevant to measure local adaptation [52].

However, the fact that foreign populations behave as well, sometimes better, than local ones, shows the flexibility of these varieties [62], which depends more on their inherent diversity than their local adaptation. This is highly relevant information for farmers collectives as it underlines the importance of seeds and information exchanges within their network so that each farmer can benefit from the work of the collective. It also supports the statement that farmers should be encouraged to collectively organise and test many varieties in order to select a few that can best fit their practices and pedoclimatic conditions. This selection can be organized in the framework of a PPB programme developing the most appropriate methods and tools for this task [40-42,63].

\subsection{Spatio-Temporal Stability of PPB Populations and Commercial Varieties}

Farmers are looking for stability in production over time, especially in organic farming where biotic and abiotic stresses cannot be tempered by chemical inputs. In France, this has resulted in an increased use of variety mixtures in recent years [64] by farmers in organic as well as in conventional farming. In another approach studying stability on the same experiment [46] using dynamic indicators (Wricke's ecovalences), it was found that all PPB populations were more stable over farms than commercial lines for GY, and some of them were more stable for PC than the two commercial lines. All PPB populations were also more stable in time than the two commercial lines for PC. However these indicators are not the most relevant for farmers as they consider the relative response with regards to the mean per farm or year. Here, using a static indicator of stability, results show that PPB populations were more stable in time than commercial varieties for protein content, and that this stability was linked to the genetic diversity within populations. Despite the fact that only two 
commercial varieties were studied here, they are very commonly used by organic farmers in France, especially Renan for its rusticity. Results showed that PPB populations were more stable over time than Hendrix for grain yield; however, Renan's temporal stability was closer to the ones of populations. This might explain why this variety has been, and continues to be, widely cultivated by organic farmers in France, representing 15\% of organic wheat acreage in 2015 [65].

Results showed that commercial varieties were less stable across farms in terms of grain yield than PPB populations, which highlights the fact that homogeneous commercial varieties are sensitive to poor conditions but valorize better fertile environments [46]. This productivity stability of PPB populations seems to be associated with greater stability in tillering capacity rather than in grain filling as indicated by the more stable grain number per $\mathrm{m}^{2}$. Raggi et al. [66] obtained similar results when comparing a Composite Cross Population (CCP) and a mixture of lines selected within this CCP with control lines selected under high input conditions, the heterogeneous varieties showing higher static and dynamic stability over environments than the homogeneous controls.

No correlation was found between stability of grain yield and genetic diversity, while studies showed that more varietal diversity usually leads to greater stability $[45,67]$. While general genetic diversity at neutral markers is not correlated with yield stability, this stability might be well explained by the diversity in specific loci involved in traits related to plant competition for resources [25].

\section{Conclusions}

The analyses presented in this study show that PPB populations are flexible enough to behave well in contrasted environments, and that they present temporal and spatial stability for protein and grain yield respectively. Thus, this kind of varieties seems suitable for organic or agroecological practices in a context of climate change in which heterogeneity is present both in space and time. The development of populations relying on diversity and the reappropriation of on-farm breeding knowledge by a collective of farmers, facilitators and research teams contribute to other important aspects of agroecology that are seed sovereignty [68] and farmers empowerment. The autonomy conferred by the on-farm selection and production of seeds, together with the combination of farmers' knowledge [69] with scientific approaches, contributes to the development of varieties compatible with a sustainable agriculture. Finally, given the within- and between-variety genetic diversity of these varieties, their deployment in agricultural landscapes is expected to increase the cultivated genetic diversity at the landscape level. This should also contribute to stabilizing the agricultural production since diversity at larger spatial scales offers a buffer against biotic and abiotic stresses [10,70].

Supplementary Materials: The following are available online at http:/ / www.mdpi.com/2071-1050/12/1/384/s1, Figure S1: Trial locations climatic data (monthly rainfall and mean temperatures); Table S2: Mean values and standard errors of varieties in each farm and each year.

Author Contributions: Conceptualization, methodology and validation, G.v.F., I.G. and P.R.; software, data curation, formal analysis, visualization and writing-original draft preparation, G.v.F.; investigation, P.R., I.G., R.B., J.-F.B., F.C., C.D., J.-S.G., A.H., F.M., H.M., B.R., S.P. and G.v.F.; writing-review \& editing, G.v.F., I.G. and P.R.; resources (populations and on-farm trials), R.B., J.-F.B, J.-S.G., C.D., F.C., F.M. and B.R.; supervision and project administration, I.G.; funding acquisition, I.G. and P.R. All authors have read and agreed to the published version of the manuscript.

Funding: This work was supported by Fondation de France (EcoAgri) and the European Union's Horizon 2020 research and innovation programme under grant agreement No 633571 (DIVERSIFOOD).

Acknowledgments: We thank Fabrice Dumas, Harry Belcram and Matthieu Falque for their assistance with DNA extraction, and students who helped collect data on the field. We are also grateful to the anonymous reviewers for their helpful comments in improving this manuscript.

Conflicts of Interest: The authors declare no conflict of interest. 


\section{Abbreviations}

The following abbreviations are used in this manuscript:

GY grain yield

LLSD last leaf to spike distance

TKW thousand kernel weight

GN number of grains per $\mathrm{m}^{2}$

NSPK number of spikelets per spike

PC protein content

$\mathrm{PH} \quad$ plant height

PPB Participatory Plant Breeding

NSPK_st proportion of sterile kernels

SL spike length

SW spike weight

\section{Appendix A. Temporal Stability for Remaining Traits}

Table A1. Variation coefficients for each factor. Y: Year; F: Farm; FY: Farm $\times$ Year interaction; Res: Residual. PPB: PPB populations; CV: Commercial varieties. Bold: significant at $5 \%$, Italic: significant at $10 \%$. ${ }^{a}$ : individual data; ${ }^{b}$ : plot data. LLSD: last leaf to spike distance; SL: spike length; SW: spike weight; NSPK: number of spikelets per spike; NSPK_st: proportion of sterile kernels.

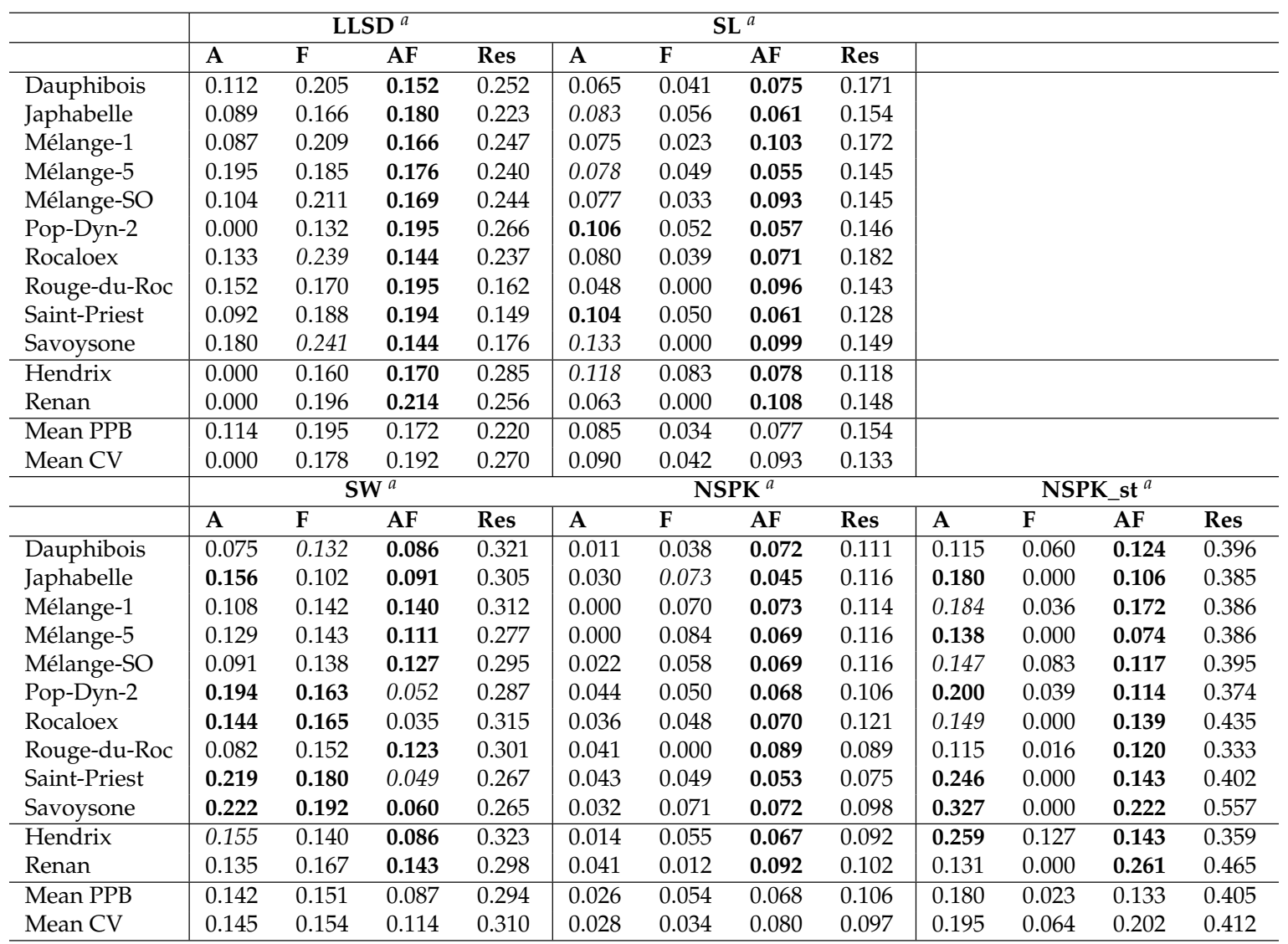




\section{Appendix B. Markers Used for Genotyping}

Appendix B.1. Markers in Neutral Zones

Table A2. Markers in neutral zones used for genotyping, chromosome position (chr) and references (ref).

\begin{tabular}{|c|c|c|c|c|c|}
\hline Marker Name & Chr & Ref & Marker Name & Chr & Ref \\
\hline wsnp_BE443995B_Ta_2_2 & $3 \mathrm{~A}$ & $9 \mathrm{~K}$ & wsnp_Ex_c11265_18216936 & $5 B$ & $9 \mathrm{~K}$ \\
\hline wsnp_Ex_c1255_2411550 & $1 \mathrm{~A}$ & $9 \mathrm{~K}$ & wsnp_BE445506B_Ta_2_4 & $7 \mathrm{~B}$ & $9 \mathrm{~K}$ \\
\hline wsnp_BE489326B_Ta_2_1 & $3 B$ & $9 \mathrm{~K}$ & wsnp_Ex_c18616_27481826 & & $9 \mathrm{~K}$ \\
\hline wsnp_Ex_c18800_27681277 & $7 \mathrm{~B}$ & $9 \mathrm{~K}$ & wsnp_Ex_c26312_35558700 & $5 B$ & $9 \mathrm{~K}$ \\
\hline wsnp_Ex_c38105_45710671 & $5 B$ & $9 \mathrm{~K}$ & wsnp_Ex_c62701_62229607 & $5 \mathrm{~A}$ & $9 \mathrm{~K}$ \\
\hline wsnp_Ex_c18965_27868480 & $6 \mathrm{~A}$ & $9 \mathrm{~K}$ & wsnp_Ex_c8588_14419007 & $1 \mathrm{~A}$ & $9 \mathrm{~K}$ \\
\hline wsnp_Ex_c9502_15748469 & $6 \mathrm{~A}$ & $9 \mathrm{~K}$ & wsnp_Ex_c9763_16125630 & $6 \mathrm{~A}$ & $9 \mathrm{~K}$ \\
\hline wsnp_Ex_rep_c102707_87814407 & $7 \mathrm{~B}$ & $9 \mathrm{~K}$ & wsnp_Ex_rep_c103087_88123733 & $1 \mathrm{~A}$ & $9 \mathrm{~K}$ \\
\hline wsnp_BF484606A_TA_2_3 & $1 \mathrm{~A}$ & $9 \mathrm{~K}$ & wsnp_Ex_rep_c66389_64588992 & $1 \mathrm{~B}$ & $9 \mathrm{~K}$ \\
\hline wsnp_Ex_rep_c70036_68988728 & $6 \mathrm{~B}$ & $9 \mathrm{~K}$ & wsnp_BG606986A_TA_2_4 & $1 \mathrm{~A}$ & $9 \mathrm{~K}$ \\
\hline wsnp_JD_c19925_17854742 & $7 \mathrm{~A}$ & $9 \mathrm{~K}$ & wsnp_JD_c20555_18262260 & $7 \mathrm{~A}$ & $9 \mathrm{~K}$ \\
\hline wsnp_BM $136727 \bar{B} \_T a \_2 \_6$ & $6 \mathrm{~B}$ & $9 \mathrm{~K}$ & wsnp_BM140362A_A_Ta_2_2 & $1 \mathrm{~A}$ & $9 \mathrm{~K}$ \\
\hline wsnp_BQ161779B_Ta_2_4 & $6 \mathrm{~B}$ & $9 \mathrm{~K}$ & BS00077147 ${ }^{m}$ & 7D & Kaspar db \\
\hline wsnp_Ku_c3151_5892200 & $5 B$ & $9 \mathrm{~K}$ & BS00022478 & $2 \mathrm{~B}$ & Kaspar db \\
\hline wsnp_Ku_c3929_7189422 & $7 \mathrm{~A}$ & $9 \mathrm{~K}$ & BS00021865 & $2 \mathrm{D}$ & Kaspar db \\
\hline wsnp_Ku_rep_c70220_69775367 & $5 \mathrm{~B}$ & $9 \mathrm{~K}$ & BS00060226 & $4 \mathrm{~A}$ & Kaspar db \\
\hline wsnp_Ku_rep_c73198_72796386 & 3B & $9 \mathrm{~K}$ & BS00064002 & $4 \mathrm{D}$ & Kaspar db \\
\hline wsnp_Ra_c107797_91270622 & $2 \mathrm{~A}$ & $9 \mathrm{~K}$ & BS00022277 & $5 \mathrm{D}$ & Kaspar db \\
\hline wsnp_Ku_c13204_21105694 & $3 \mathrm{D}$ & $9 \mathrm{~K}$ & BS00080040 & $6 \mathrm{D}$ & Kaspar db \\
\hline wsnp_JG_c625_379570 & $5 \mathrm{~B}$ & $9 \mathrm{~K}$ & BS00096478 ${ }^{m}$ & $7 \mathrm{D}$ & Kaspar db \\
\hline wsnp_Ku_c33335_42844594 & $3 B$ & $9 \mathrm{~K}$ & BS00026412 & $2 \mathrm{~B}$ & Kaspar db \\
\hline wsnp_Ku_c51039_56457361 & $5 \mathrm{~A}$ & $9 \mathrm{~K}$ & BS00023211 & $2 \mathrm{D}$ & Kaspar db \\
\hline wsnp_Ku_rep_c72211_71920520 & $5 B$ & $9 \mathrm{~K}$ & BS00065607 & $4 \mathrm{~A}$ & Kaspar db \\
\hline wsnp_Ra_c1020_2062200 & 1D & $9 \mathrm{~K}$ & BS00068103 & $4 \mathrm{D}$ & Kaspar db \\
\hline wsnp_CAP12_c7952_3403722 & $5 B$ & $9 \mathrm{~K}$ & BS00085191 & $5 \mathrm{D}$ & Kaspar db \\
\hline wsnp_Ra_c425̄4_7755 4993 & $6 \mathrm{~B}$ & $9 \mathrm{~K}$ & BS00087343 & $6 \mathrm{D}$ & Kaspar $\mathrm{db}$ \\
\hline
\end{tabular}

${ }^{m}$ : monomorphic. 9K: 9K iSelect assay. Kaspar db: Kaspar database. Chromosomic positions are from Cavanagh et al. [71].

Appendix B.2. Markers in Candidate Genes for Precocity

Table A3. Markers in candidate genes for precocity, chromosome position (chr) and references (ref).

\begin{tabular}{llllll}
\hline Candidate Gene & Associated Trait & Chr & Polymorphism & Ref & Marker Name \\
\hline PHYA & photoreceptors & 4A & SNP & 9K & wsnp_Ex_c1563_2987002 \\
ZTL & photoreceptors & 6B & SNP & 9K & wsnp_Ex_c18382_27210656 \\
VIL2 & vernalization & 6B & SNP & 9K & wsnp_Ex_c39304_46635517 \\
SMZ & photoperiod & 1B & SNP & $9 \mathrm{~K}$ & wsnp_BE_403956B_Ta_2_3 \\
Vrn1B & vernalization & 1A & SNP & 9K & wsnp_Ex_c645_1273901 \\
Vrn1B & vernalization & 6A & SNP & 9K & wsnp_Ex_c7546_12900094 \\
SMZ & photoperiod & 1B & SNP & 9K & wsnp_Ex_c9063_15093396 \\
PHYA & photoreceptors & 4A & SNP & 9K & wsnp_Ex_rep_c66600_64897324 \\
C04 & photoperiod & 5B & SNP & 9K & wsnp_Ex_rep_c67690_66354931 \\
Vrn1B & vernalization & 6A & SNP & 9K & wsnp_Ex_rep_c69901_68864080 \\
CO1 & photoperiod & 7A & SNP & 9K & wsnp_JD_c15333_14824351 \\
TaHd1A & photoperiod & 5A & SNP & 9K & wsnp_Ku_c15816_24541712 \\
CO1 & photoperiod & 3B & SNP & 9K & wsnp_Ku_c48167_54427241 \\
SMZ & photoperiod & 4A & SNP & 9K & wsnp_CAP11_c3346_1639010 \\
SOC1 & photoperiod & 3A & SNP & 9K & wsnp_Ra_c16053_24607526 \\
C04 ${ }^{\text {out }}$ & photoperiod & 7A & SNP & 9K & wsnp_CAP12_c1461_744121 \\
ZTL & photoreceptors & 6B & SNP & 9K & wsnp_Ra_c3766_6947953 \\
\hline
\end{tabular}


Table A3. Cont.

\begin{tabular}{|c|c|c|c|c|c|}
\hline Candidate Gene & Associated Trait & Chr & Polymorphism & Ref & Marker Name \\
\hline Vrn1A & vernalization & $5 \mathrm{~A}$ & SNP & [72] & \\
\hline Vrn1A & vernalization & $5 \mathrm{~A}$ & SNP & [72] & \\
\hline Vrn1B & vernalization & $5 B$ & SNP & [72] & \\
\hline Vrn1B & vernalization & $5 B$ & SNP & [72] & \\
\hline Vrn1A & vernalization & $5 \mathrm{~A}$ & SNP & [73] & \\
\hline Vrn1B & vernalization & $5 \mathrm{~B}$ & SNP & [74] & \\
\hline $\operatorname{Vrn} 3 B^{m}$ & vernalization & $7 \mathrm{~B}$ & SNP & [75] & \\
\hline $\operatorname{Vrn} 1 B^{m}$ & vernalization & $5 B$ & $6849 \mathrm{bp}$ indel & [72] & \\
\hline TaGI3 & photoperiod & $3 B$ & SNP & [76] & wsnp_Ex_rep_c67404_65986980 \\
\hline LDDA & photoperiod & $5 \mathrm{~A}$ & SNP & [76] & wsnp_Ku_c1102_2211433 \\
\hline CO-B & photoperiod & $5 B$ & SNP & [77] & \\
\hline FTA & flowering & $7 \mathrm{~A}$ & SSR & [78] & \\
\hline Ppd-D1 ${ }^{m}$ & photoperiod & $2 \mathrm{D}$ & $2 \mathrm{~kb}$ indel & [79] & \\
\hline Vrn1A & vernalization & $5 \mathrm{~A}$ & SNP & [73] & \\
\hline Vrn1D & vernalization & $5 \mathrm{D}$ & $4 \mathrm{~kb}$ indel & [72] & \\
\hline TaGW2 & grain size & $6 \mathrm{~A}$ & SNP & [80] & \\
\hline Ppd-D1 & photoperiod & $2 \mathrm{~A}$ & 305bp indel & [81] & \\
\hline
\end{tabular}

\section{References}

1. Ray, D.K.; Gerber, J.S.; MacDonald, G.K.; West, P.C. Climate variation explains a third of global crop yield variability. Nat. Commun. 2015, 6. [CrossRef] [PubMed]

2. Bren d'Amour, C.; Wenz, L.; Kalkuhl, M.; Christoph Steckel, J.; Creutzig, F. Teleconnected food supply shocks. Environ. Res. Lett. 2016, 11, 035007. [CrossRef]

3. Liu, B.; Martre, P.; Ewert, F.; Porter, J.R.; Challinor, A.J.; Müller, C.; Ruane, A.C.; Waha, K.; Thorburn, P.J.; Aggarwal, P.K.; et al. Global wheat production with 1.5 and $2.0^{\circ} \mathrm{C}$ above pre-industrial warming. Glob. Chang. Biol. 2018, 25, 1428-1444. [CrossRef] [PubMed]

4. Trnka, M.; Rötter, R.P.; Ruiz-Ramos, M.; Kersebaum, K.C.; Olesen, J.E.; Žalud, Z.; Semenov, M.A. Adverse weather conditions for European wheat production will become more frequent with climate change. Nat. Clim. Chang. 2014, 4, 637-643. [CrossRef]

5. Kahiluoto, H.; Kaseva, J.; Balek, J.; Olesen, J.E.; Ruiz-Ramos, M.; Gobin, A.; Kersebaum, K.C.; Takáč, J.; Ruget, F.; Ferrise, R.; et al. Decline in climate resilience of European wheat. Proc. Natl. Acad. Sci. USA 2019, 116, 123-128. [CrossRef] [PubMed]

6. Frison, E.A.; Cherfas, J.; Hodgkin, T. Agricultural biodiversity is essential for a sustainable improvement in food and nutrition security. Sustainability 2011, 3, 238-253. [CrossRef]

7. Abson, D.J.; Fraser, E.D.; Benton, T.G. Landscape diversity and the resilience of agricultural returns: A portfolio analysis of land-use patterns and economic returns from lowland agriculture. Agric. Food Secur. 2013, 2, 2. [CrossRef]

8. Altieri, M.A. The ecological role of biodiversity in agroecosystems. Agric. Ecosyst. Environ. 1999, 74, 19-31. [CrossRef]

9. Gaudin, A.C.M.; Tolhurst, T.N.; Ker, A.P.; Janovicek, K.; Tortora, C.; Martin, R.C.; Deen, W. Increasing crop diversity mitigates weather variations and improves yield stability. PLoS ONE 2015, 10, e0113261. [CrossRef]

10. Renard, D.; Tilman, D. National food production stabilized by crop diversity. Nature 2019, 571, 257-260. [CrossRef]

11. De Vallavieille-Pope, C. Management of disease resistance diversity of cultivars of a species in single fields: Controlling epidemics. Comptes Rendus Biol. 2004, 327, 611-620. [CrossRef] [PubMed]

12. Mundt, C.C. Use of multiline cultivars and cultivar mixtures for disease management. Annu. Rev. Phytopathol. 2002, 40, 381-410. [CrossRef] [PubMed]

13. Altieri, M.A.; Nicholls, C.I. The adaptation and mitigation potential of traditional agriculture in a changing climate. Clim. Chang. 2013, 140, 33-45. [CrossRef] 
14. Østergård, H.; Finckh, M.R.; Fontaine, L.; Goldringer, I.; Hoad, S.P.; Kristensen, K.; van Bueren, E.T.L.; Mascher, F.; Munk, L.; Wolfe, M.S. Time for a shift in crop production: Embracing complexity through diversity at all levels. J. Sci. Food Agric. 2009, 89, 1439-1445. [CrossRef]

15. Finckh, M.; Gacek, E.; Goyeau, H.; Lannou, C.; Merz, U.; Mundt, C.; Munk, L.; Nadziak, J.; Newton, A.; de Vallavieille-Pope, C.; et al. Cereal variety and species mixtures in practice, with emphasis on disease resistance. Agronomie 2000, 20, 813-837. [CrossRef]

16. Cardinale, B.J.; Matulich, K.L.; Hooper, D.U.; Byrnes, J.E.; Duffy, E.; Gamfeldt, L.; Balvanera, P.; O'Connor, M.I.; Gonzalez, A. The functional role of producer diversity in ecosystems. Am. J. Bot. 2011, 98, 572-592. [CrossRef]

17. Cook-Patton, S.C.; McArt, S.H.; Parachnowitsch, A.L.; Thaler, J.S.; Agrawal, A.A. A direct comparison of the consequences of plant genotypic and species diversity on communities and ecosystem function. Ecology 2011, 92, 915-923. [CrossRef]

18. Tilman, D.; Lehman, C.L.; Thomson, K.T. Plant diversity and ecosystem productivity: Theoretical considerations. Proc. Natl. Acad. Sci. USA 1997, 94, 1857-1861. [CrossRef]

19. Goldringer, I.; Serpolay, E.; Rey, F.; Costanzo, A. Varieties and populations for on-farm participatory plant breeding. DIVERSIFOOD Innovation Factsheet 2; 2017. Available online: http://www.diversifood.eu/ wp-content/uploads/2018/06/Diversifood_innovation_factsheet2_VarietiesPopulations.pdf (accessed on 2 January 2020).

20. Reiss, E.R.; Drinkwater, L.E. Cultivar mixtures: A meta-analysis of the effect of intraspecific diversity on crop yield. Ecol. Appl. 2018, 28, 62-78. [CrossRef]

21. Tomich, T.P.; Brodt, S.; Ferris, H.; Galt, R.; Horwath, W.R.; Kebreab, E.; Leveau, J.H.; Liptzin, D.; Lubell, M.; Merel, P.; et al. Agroecology: A review from a global-change perspective. Annu. Rev. Environ. Resour. 2011, 36, 193-222. [CrossRef]

22. Barot, S.; Allard, V.; Cantarel, A.; Enjalbert, J.; Gauffreteau, A.; Goldringer, I.; Lata, J.C.; Le Roux, X.; Niboyet, A.; Porcher, E. Designing mixtures of varieties for multifunctional agriculture with the help of ecology. A review. Agron. Sustain. Dev. 2017, 37, 13. [CrossRef]

23. Kiær, L.P.; Skovgaard, I.M.; Østergård, H. Grain yield increase in cereal variety mixtures: A meta-analysis of field trials. Field Crop. Res. 2009, 114, 361-373. [CrossRef]

24. Prieto, I.; Violle, C.; Barre, P.; Durand, J.L.; Ghesquiere, M.; Litrico, I. Complementary effects of species and genetic diversity on productivity and stability of sown grasslands. Nat. Plants 2015, 1, 15033. [CrossRef] [PubMed]

25. Helland, S.J.; Holland, J.B. Genome-wide genetic diversity among components does not cause cultivar blend responses. Crop Sci. 2003, 43, 1618-1627. [CrossRef]

26. Houle, D. Comparing evolvability and variability of quantitative traits. Genetics 1992, 130, $195-204$. [PubMed]

27. Kawecki, T.J.; Ebert, D. Conceptual issues in local adaptation. Ecol. Lett. 2004, 7, 1225-1241. [CrossRef]

28. Leimu, R.; Fischer, M. A meta-analysis of local adaptation in plants. PLoS ONE 2008, 3, e4010. [CrossRef]

29. Linhart, Y.B.; Grant, M.C. Evolutionary significance of local genetic differentiation in plants. Annu. Rev. Ecol. Syst. 1996, 27, 237-277. [CrossRef]

30. Galloway, L.F.; Fenster, C.B. Population differentiation in an annual legume: Local adaptation. Evolution 2000, 54, 1173-1181. [CrossRef]

31. Blanquart, F.; Kaltz, O.; Nuismer, S.L.; Gandon, S. A practical guide to measuring local adaptation. Ecol. Lett. 2013, 16, 1195-1205. [CrossRef]

32. Horneburg, B.; Becker, H.C. Crop adaptation in on-farm management by natural and conscious selection: A case study with lentil. Crop Sci. 2008, 48, 203-212. [CrossRef]

33. Klaedtke, S.; Caproni, L.; Klauck, J.; de la Grandville, P.; Dutartre, M.; Stassart, P.; Chable, V.; Negri, V.; Raggi, L. Short-term local adaptation of historical common bean (Phaseolus vulgaris L.) varieties and implications for in situ management of bean diversity. Int. J. Mol. Sci. 2017, 18, 493. [CrossRef] [PubMed]

34. Dawson, J.C.; Murphy, K.M.; Jones, S.S. Decentralized selection and participatory approaches in plant breeding for low-input systems. Euphytica 2008, 160, 143-154. [CrossRef]

35. Ceccarelli, S. Wide adaptation: How wide? Euphytica 1989, 40, 197-205. [CrossRef] 
36. Desclaux, D.; Nolot, J.M.; Chiffoleau, Y.; Gozé, E.; Leclerc, C. Changes in the concept of genotype $\times$ environment interactions to fit agriculture diversification and decentralized participatory plant breeding: pluridisciplinary point of view. Euphytica 2008, 163, 533-546. [CrossRef]

37. Witcombe, J.; Yadavendra, J. How much evidence is needed before client-oriented breeding (COB) is institutionalised? Evidence from rice and maize in India. Field Crop. Res. 2014, 167, 143-152. [CrossRef]

38. Ceccarelli, S. Efficiency of Plant Breeding. Crop Sci. 2015, 55, 87-97. [CrossRef]

39. Witcombe, J.R.; Joshi, A.; Goyal, S.N. Participatory plant breeding in maize: A case study from Gujarat, India. Euphytica 2003, 130, 413-422. [CrossRef]

40. Rivière, P.; Pin, S.; Galic, N.; de Oliviera, Y.; David, O.; Dawson, J.; Wanner, A.; Heckmann, R.; Obbellianne, S.; Ronot, B.; et al. Mise en place d'une méthodologie de sélection participative sur le blé tendre en France. Innov. Agron. 2013, 32, 427-441.

41. Rivière, P.; Dawson, J.C.; Goldringer, I.; David, O. Hierarchical Bayesian modeling for flexible experiments in decentralized participatory plant breeding. Crop Sci. 2015, 55, 1053-1067. [CrossRef]

42. Van Frank, G.; Goldringer, I.; Rivière, P.; David, O. Influence of experimental design on decentralized, on-farm evaluation of populations: A simulation study. Euphytica 2019, 215, 126. [CrossRef]

43. Borg, J.; Kiær, L.; Lecarpentier, C.; Goldringer, I.; Gauffreteau, A.; Saint-Jean, S.; Barot, S.; Enjalbert, J. Unfolding the potential of wheat cultivar mixtures: A meta-analysis perspective and identification of knowledge gaps. Field Crop. Res. 2017, 221, 298-313. [CrossRef]

44. Creissen, H.E.; Jorgensen, T.H.; Brown, J.K.M. Increased yield stability of field-grown winter barley (Hordeum vulgare L.) varietal mixtures through ecological processes. Crop Prot. 2016, 85, 1-8. [CrossRef] [PubMed]

45. Döring, T.F.; Annicchiarico, P.; Clarke, S.; Haigh, Z.; Jones, H.E.; Pearce, H.; Snape, J.; Zhan, J.; Wolfe, M.S. Comparative analysis of performance and stability among composite cross populations, variety mixtures and pure lines of winter wheat in organic and conventional cropping systems. Field Crop. Res. 2015, 183, 235-245. [CrossRef]

46. Goldringer, I.; van Frank, G.; Bouvier d'Yvoire, C.; Forst, E.; Galic, N.; Garnault, M.; Locqueville, J.; Pin, S.; Bailly, J.; Baltassat, R.; et al. Agronomic evaluation of bread wheat varieties from participatory breeding: A combination of performance and robustness. Sustainability 2020, 12, 128. [CrossRef]

47. LGC Biosearch Technologies. KASP Genotyping Chemistry. Available online: https://www.biosearchtech. $\mathrm{com} /$ products/pcr-kits-and-reagents/genotyping-assays/kasp-genotyping-chemistry (accessed on 13 August 2019).

48. R Core Team. R: A Language and Environment for Statistical Computing; R Foundation for Statistical Computing: Vienna, Austria, 2018.

49. Jombart, T.; Ahmed, I. Adegenet 1.3-1: New tools for the analysis of genome-wide SNP data. Bioinformatics 2011. [CrossRef]

50. Nei, M. Analysis of gene diversity in subdivided populations. Proc. Natl. Acad. Sci. USA 1973, 70, $3321-3323$. [CrossRef]

51. Riviere, P.; van Frank, G.; David, O.; Muñoz, F.; Rouger, B.; Vindras, C.; Thomas, M.; Goldringer, I. PPBstats: An R Package to Perform Analysis Found within PPB Programmes Regarding Network of Seeds Circulation, Agronomic Trials, Organoleptic Tests and Molecular Experiments, version 0.25; 2019. Available online: https: / / github.com/priviere/PPBstats_web_site (accessed on 2 January 2020).

52. Serpolay, E.; Dawson, J.C.; Chable, V.; Van Bueren, E.L.; Osman, A.; Pino, S.; Silveri, D.; Goldringer, I. Diversity of different farmer and modern wheat varieties cultivated in contrasting organic farming conditions in western Europe and implications for European seed and variety legislation. Org. Agric. 2011, 1, 127-145. [CrossRef]

53. Ceccarelli, S.; Grando, S. Decentralized-participatory plant breeding: An example of demand driven research. Euphytica 2007, 155, 349-360. [CrossRef]

54. Raggi, L.; Ceccarelli, S.; Negri, V. Evolution of a barley composite cross-derived population: An insight gained by molecular markers. J. Agric. Sci. 2016, 154, 23-39. [CrossRef]

55. Enjalbert, J.; Dawson, J.C.; Paillard, S.; Rhoné, B.; Rousselle, Y.; Thomas, M.; Goldringer, I. Dynamic management of crop diversity: From an experimental approach to on-farm conservation. Comptes Rendus Biol. 2011, 334, 458-468. [CrossRef] [PubMed]

56. Goldringer, I.; Enjalbert, J.; Raquin, A.L.; Brabant, P. Strong selection in wheat populations during ten generations of dynamic management. Genet. Sel. Evol. 2001, 33, S441-S463. [CrossRef] 
57. Goldringer, I.; Prouin, C.; Rousset, M.; Galic, N.; Bonnin, I. Rapid differentiation of experimental populations of wheat for heading time in response to local climatic conditions. Ann. Bot. 2006, 98, 805-817. [CrossRef] [PubMed]

58. Thomas, M.; Thépot, S.; Galic, N.; Jouanne-Pin, S.; Remoué, C.; Goldringer, I. Diversifying mechanisms in the on-farm evolution of crop mixtures. Mol. Ecol. 2015, 24, 2937-2954. [CrossRef] [PubMed]

59. Rhoné, B.; Vitalis, R.; Goldringer, I.; Bonnin, I. Evolution of flowering time in experimental wheat populations: A comprehensive approach to detect genetic signatures of natural selection. Evolution 2010, 64, 2110-2125. [CrossRef] [PubMed]

60. Becker, U.; Colling, G.; Dostal, P.; Jakobsson, A.; Matthies, D. Local adaptation in the monocarpic perennial Carlina vulgaris at different spatial scales across Europe. Oecologia 2006, 150, 506-518. [CrossRef]

61. Dawson, J.C.; Serpolay, E.; Giuliano, S.; Schermann, N.; Galic, N.; Berthellot, J.F.; Chesneau, V.; Ferté, H.; Mercier, F.; Osman, A.; et al. Phenotypic diversity and evolution of farmer varieties of bread wheat on organic farms in Europe. Genet. Resour. Crop Evol. 2013, 60, 145-163. [CrossRef]

62. Crispo, E. Modifying effects of phenotypic plasticity on interactions among natural selection, adaptation and gene flow. J. Evol. Biol. 2008, 21, 1460-1469. [CrossRef]

63. Dawson, J.C.; Rivière, P.; Berthellot, J.F.; Mercier, F.; Kochko, P.d.; Galic, N.; Pin, S.; Serpolay, E.; Thomas, M.; Giuliano, S.; et al. Collaborative plant breeding for organic agricultural systems in developed countries. Sustainability 2011, 3, 1206-1223. [CrossRef]

64. Magnard, A. Mélanger les variétés de blé, une pratique qui monte. Fr. Agric. 2017, 3724, 37.

65. FranceAgriMer. Variétés et rendements des céréales biologiques. Récolte 2015; FranceAgriMer: Montreuil, France, 2016.

66. Raggi, L.; Ciancaleoni, S.; Torricelli, R.; Terzi, V.; Ceccarelli, S.; Negri, V. Evolutionary breeding for sustainable agriculture: Selection and multi-environmental evaluation of barley populations and lines. Field Crop. Res. 2017, 204, 76-88. [CrossRef]

67. Creissen, H.E.; Jorgensen, T.H.; Brown, J.K.M. Stabilization of yield in plant genotype mixtures through compensation rather than complementation. Ann. Bot. 2013, 112, 1439-1447. [CrossRef] [PubMed]

68. Kloppenburg, J. Impeding dispossession, enabling repossession: Biological open source and the recovery of seed sovereignty. J. Agrar. Chang. 2010, 10, 367-388. [CrossRef]

69. Stassart, P.M.; Baret, P.; Grégoire, J.C.; Hance, T. L'agroécologie: Trajectoire et potentiel pour une transition vers des systèmes alimentaires durables. In Agroécologie entre pratiques et sciences sociales, Educagri Editions; Dam, D.V., Streith, M., Nizet, J., Stassart, P.M., Eds.; Educagri: Dijon, France, 2012; pp. 25-51.

70. Wolfe, M.S.; Brandle, U.; Koller, B.; Limpert, E.; McDermott, J.M.; Miiller, K.; Schaffner, D. Barley mildew in Europe: Population biology and host resistance. Euphytica 1992, 63, 125-139. [CrossRef]

71. Cavanagh, C.R.; Chao, S.; Wang, S.; Huang, B.E.; Stephen, S.; Kiani, S.; Forrest, K.; Saintenac, C.; Brown-Guedira, G.L.; Akhunova, A.; et al. Genome-wide comparative diversity uncovers multiple targets of selection for improvement in hexaploid wheat landraces and cultivars. Proc. Natl. Acad. Sci. USA 2013, 110, 8057-8062. [CrossRef] [PubMed]

72. Fu, D.; Szúcs, P.; Yan, L.; Helguera, M.; Skinner, J.S.; von Zitzewitz, J.; Hayes, P.M.; Dubcovsky, J. Large deletions within the first intron in VRN-1 are associated with spring growth habit in barley and wheat. Mol. Genet. Genom. 2005, 273, 54-65. [CrossRef]

73. Sherman, J.D.; Yan, L.; Talbert, L.; Dubcovsky, J. A PCR marker for growth habit in common wheat based on allelic variation at the VRN-A1 gene. Crop Sci. 2004, 44, 1832-1838. [CrossRef]

74. Shcherban, A.B.; Efremova, T.T.; Salina, E.A. Identification of a new Vrn-B1 allele using two near-isogenic wheat lines with difference in heading time. Mol. Breed. 2012, 29, 675-685. [CrossRef]

75. Yan, L.; Fu, D.; Li, C.; Blechl, A.; Tranquilli, G.; Bonafede, M.; Sanchez, A.; Valarik, M.; Yasuda, S.; Dubcovsky, J. The wheat and barley vernalization gene VRN3 is an orthologue of FT. Proc. Natl. Acad. Sci. USA 2006, 103, 19581-19586. [CrossRef]

76. Rhoné, B. Etude des mécanismes génétiques impliqués dans l'adaptation climatique de populations expérimentales de blé tendre. Ph.D. Thesis, AgroParisTech, Paris, France, 2008.

77. Rhoné, B.; Remoué, C.; Galic, N.; Goldringer, I.; Bonnin, I. Insight into the genetic bases of climatic adaptation in experimentally evolving wheat populations. Mol. Ecol. 2008, 17, 930-943. [CrossRef] 
78. Bonnin, I.; Rousset, M.; Madur, D.; Sourdille, P.; Dupuits, C.; Brunel, D.; Goldringer, I. FT genome A and D polymorphisms are associated with the variation of earliness components in hexaploid wheat. Theor. Appl. Genet. 2008, 116, 383-394. [CrossRef] [PubMed]

79. Beales, J.; Turner, A.; Griffiths, S.; Snape, J.W.; Laurie, D.A. A Pseudo-Response Regulator is misexpressed in the photoperiod insensitive Ppd-D1a mutant of wheat (Triticum aestivum L.). Theor. Appl. Genet. 2007, 115, 721-733. [CrossRef] [PubMed]

80. Su, Z.; Hao, C.; Wang, L.; Dong, Y.; Zhang, X. Identification and development of a functional marker of TaGW2 associated with grain weight in bread wheat (Triticum aestivum L.). Theor. Appl. Genet. 2011, 122, 211-223. [CrossRef] [PubMed]

81. Wilhelm, E.P.; Turner, A.S.; Laurie, D.A. Photoperiod insensitive $P P d-A 1 a$ mutations in tetraploid wheat (Triticum durum Desf.). Theor. Appl. Genet. 2009, 118, 285-294. [CrossRef]

82. Akhunov, E.D.; Akhunova, A.R.; Anderson, O.D.; Anderson, J.A.; Blake, N.; Clegg, M.T.; Coleman-Derr, D.; Conley, E.J.; Crossman, C.C.; Deal, K.R.; et al. Nucleotide diversity maps reveal variation in diversity among wheat genomes and chromosomes. BMC Genom. 2010, 11, 702. [CrossRef]

83. Chao, S.; Dubcovsky, J.; Dvorak, J.; Luo, M.C.; Baenziger, S.P.; Matnyazov, R.; Clark, D.R.; Talbert, L.E.; Anderson, J.A.; Dreisigacker, S.; et al. Population- and genome-specific patterns of linkage disequilibrium and SNP variation in spring and winter wheat (Triticum aestivum L.). BMC Genom. 2010, 11, 727. [CrossRef]

84. Higgins, J.A.; Bailey, P.C.; Laurie, D.A. Comparative genomics of flowering time pathways using Brachypodium distachyon as a model for the temperate grasses. PLoS ONE 2010, 5, e10065. [CrossRef]

(C) 2020 by the authors. Licensee MDPI, Basel, Switzerland. This article is an open access article distributed under the terms and conditions of the Creative Commons Attribution (CC BY) license (http:/ / creativecommons.org/licenses/by/4.0/). 